\title{
PELATIHAN UPSKILLING BAGI PEKERJA SEKTOR PARIWISATA TERDAMPAK COVID-19 DI PULAU LOMBOK
}

\begin{abstract}
Sri Ariani ${ }^{*}$
Ni Wayan Prami Wahyudiantari ${ }^{2}$

Heri Hidayatullah ${ }^{3}$

Aprianoto 4

I Made Permadi Utama 5

Muhammad Arief Rizka6

1*2,3,4,5,6Universitas Pendidikan Mandalika, Mataram, Indonesia

sriariani@undikma.ac.id ${ }^{*}{ }^{*}$

niwayanpramiwahyudiantari@undikma.ac.id ${ }^{2)}$

herihidayatullah@undikma.ac.id $\left.{ }^{3}\right)$

aprianoto@undikma.ac.id ${ }^{4}$

imadepermadiutama@undikma.ac.id ${ }^{5)}$

m.ariefrizka@undikma.ac.id ${ }^{6}$

Kata Kunci:

[Pelatihan, Upskilling, Pekerja, Pariwisata]

Abstrak: Covid-19 berdampak begitu nyata bagi pekerja sektor pariwisata di Lombok Barat. Sebagian besar hotel di Kabupaten Lombok Barat yang sudah memberlakukan cuti hingga merumahkan pekerjanya. Sedangkan pekerja kontrak dan tetap diberikan waktu kerja yang diatur secara bergiliran. Bagi Pekerja yang dirumahkan karena terdampak covid, tentunya berdiamdiri dirumah tanpa mengasah skill, bukanlah menjadi pilihan bijak. Sebagai pelaku pariwisata, Keterampilan yang mereka miliki pun terbatas pada Pekerjaan seperti Tukang Kebun, Cleaning Service, Pelayan Restaurant, Tukang Ojek, Penjual Souvenir, Pembuat Kerajinan dari Kayu dan Bambu. Terlebih lagi dimasa pandemi seperti saat ini, setiap pekerja dituntut untuk memiliki daya saing yang mempuni sehingga dapat bertahan dalam industri pariwisata. Hal inilah yang menggerakkan Tim Pengabdian kami untuk berperean aktif dalam Pelatihan Upskilling bagi Pekerja Sektor Pariwisata yang terdampak Covid-19. Sehingga diharapkan dapat mengoptimalkan skill mereka khususnya English Speaking Skill sehingga pada saat mereka kembali bekerja dan meningkatkan penghasilan mereka. Dengan menerapkan Metode Pelatihan yang menarik dan didukung oleh materi pelatihan yang upto-dated serta disampaikan oleh para pakar dari Tim yang berpengalaman dan profesional dalam bidang pengajaran Bahasa Inggris. Materi yang disampaikan dalam Pelatihan ini antara lain materi menarik dan interaktif terkait English for Business, English for Hospitality, dan English for General Communications. Dari angket diisi oleh seluruh pekerja dan hasil dari angket kepuasan secara umum menunjukkan bahwa kegiatan PkM yang telah dilaksanakan dirasakan bermanfaat bagi para pekerja. Materi disampaikan dengan baik dan menarik. Pembicara yang dihadirkan juga dinilai baik.
\end{abstract}

Published by:

Copyright (c) 2021 The Author(s)

This article is licensed under CC BY 4.0 License

(cc) $\mathrm{BY}$

https://dmi-journals.org/jai 


\section{Pendahuluan}

Kondisi pandemic Covid-19 selama dua tahun terakhir ini, menyebabkan pariwisata di Indonesia ditutup. Dampaknya begitu terasa pada hampir semua sektor. Sektor pariwisata merupakan salah satu sektor penyumbang bagi pendapatan daerah. Terdapat penurunan kunjungan wisatawan mancanegara sebanyak 11,8\% pada tahun 2020. Selain itu dikemukakan bahwa terdapat pengurangan karyawan Hotel sehingga diberlakukan juga jadwal kerja secara bergantian bagi yang berstatus kontrak dan permanen (Cahyani D, 2020). Demikian juga di Lombok Barat. Semenjak adanya Covid19, anggaran pendapatan dari sektor pariwisata turun tajam. Penyebaran virus Corona menyebabkan wisatawan yang berkunjung ke Lombok Barat sangat berkurang. Dampaknya sangat terasa pada sektor penunjang pariwisata seperti hotel, restoran maupun pengusaha retail juga tidak lepas dari pengaruh adanya virus Corona. Sepinya wisatawan juga berdampak pada restoran atau rumah makan yang sebagian besar konsumennya adalah para wisatawan. Mengakibatkan begitu banyak pekerja harus kehilangan pekerjaannya.

Sehubungan dengan pengabdian kepada masyarakat, Tim Pengabdian kami tergerak untuk berperean aktif untuk melakukan upaya peningkatan Keterampilan masyarakat dalam masa pandemi ini melalui Pelatihan Upskilling bagi Pekerja Sektor Pariwisata yang terdampak Covid-19. Bahasa Inggris memiliki pengaruh yang sangat kuat dalam dunia modern dan menjadi salah satu alat komunkasi yang sangat penting dalam hubungan Internasional (Lystiana Nurhayat Hakim, Tri Agustini Solihati, 2021). Terlebih lagi dimasa pandemi seperti saat ini, setiap pekerja dituntut untuk memiliki kemampuan bahasa Inggris yang baik dan berdaya saing sehingga dapat bertahan dalam industri pariwisata.

Dengan menerapkan Metode Pelatihan yang menarik dan didukung oleh media pembelajaran yang up-to-dated. Sebagaimana yang dikemukakan oleh Estrada bahwa media pembelajaran adalah segala sesuatu yang dapat digunakan untuk menyampaikan bahan pembelajaran yang dapat menarik perhatian, minat, pikiran dan perasaan pembelajar dalam kegiatan pembelajaran sehingga tujuan belajar tercapai ( Salamah, Lindawat, Asriyadi, \& Kusumanto, 2021). Materi pembelajaran disampaikan oleh para pakar dari Tim yang berpengalaman dan profesional dalam bidang pengajaran Bahasa Inggris. Bahasa Inggris sangat dibutuhkan karena merupakan bahasa Internasional yang digunakan di sebagian besar negara di dunia dan digunakan dalam berbagai sektor terutama dalam industri Pariwisata. Inilah alasan mengapa Tim pengabdian mengambil judul Pengabdian kepada Masyarakat yaitu "Pelatihan Upskilling Bagi Pekerja Sektor Pariwisata Terdampak Covid-19 Di Desa Sesela, Kecamatan Gunungsari, Kabupaten Lombok Barat.

Materi yang disampaikan dalam Pelatihan ini antara lain materi menarik dan interaktif terkait English for Business, English for Hospitality, dan English for General Communications . Pelatihan ini diikuti oleh 20 orang Pekerja yang terdampak Covid-19 pada sektor pariwisata. Syarat penting yang harus ditempuh oleh para peserta selama pelaksanaan pelatihan yaitu peserta wajib menerapkan protokol kesehatan. Seperti pemeriksaan suhu badan, selalu memakai masker, jaga jarak, selalu mencuci tangan dan menggunakan hand sanitizer. Pelatihan ini terselenggara berkat dukungan dan kerjasama yang baik dari Para Pekerja terdampak Covid yang ada di Desa Sesela dengan Tim Pengabdian dari Prodi Bahasa Inggris FBMB dan LPPM UNDIKMA Mataram. 
Diharapkan, kegiatan ini dapat mencapai tujuannya untuk dapat mengoptimalkan Upskilling Pekerja yang terdampak Covid-19 pada sektor pariwisata. Sehingga mendukung daya saing dan dapat membangun kembali Industri Pariwisata domestik secara berkelanjutan.

\section{Metode Pelaksanaan}

Metode yang dilakukan dalam kegiatan ini adalah melalui beberapa tahap Planning (Perencanaan), Executing (Pelaksanaan) \& Evaluating (Evaluasi).

\section{Tahap Planning (Perencanaan)}

Tim PKM mendatangi lokasi pengabdian untuk memperoleh data dan informasi yang memadai. Kemudian melakukan wawancara kepada para pekerja dibidang Pariwisata tentang sejauh mana Para Pekerja mampu berkomunikasi dalam bahasa Inggris dengan tamu mancanegara. Selain itu untuk mengetahui sejauh mana mereka terdampak dengan kebijakan Pemerintah Indonesia sejak awal tahun 2021 untuk menangani Covid19 yaitu Pemberlakuan Pembatasan Kegiatan Masyarakat (PPKM). Tahap ini juga meliputi diskusi proposal, jadwal pelaksanaan kegiatan, dan rincian job drescription dari tiap-tiap anggota tim pengabdian. Dimana disepakati kegiatan PKM ini berlangung pada 29 April 2021 - 17 Mei 2021.

\section{Executing (Pelaksanaan)}

Pelaksanaan kegiatan utama disesuaikan dengan kondisi di lapangan yang terbatas mengingat masih dalam situasi Covid 19. Kegiatan PKM ini dilaksanakan dengan menerapkan protokol kesehatan seperti menggunakan masker, menjaga jarak dan membersihkan tangan dengan sabun atau handsanitizer. Materi dan Modul Panduan. Tim memberikan Materi pelatihan dan disampaikan dengan bahasa sesederhana mungkin agar mudah untuk dimengerti oleh para pekerja, mengingat mereka tidak mempunyai latar belakang Bahasa Inggris ( Diyani, Kusumawati, \& Meita, 2021). Materi pelatihan ini disusun berdasarkan hasil dari analisis kebutuhan dan diskusi secara langsung dengan para Pekerja terdampak Covid-19 yang disesuaikan dengan kebutuhan mereka, dan bersifat praktis komunikatif artinya langsung berhubungan dengan percakapan sehari hari antara lain: yang mengenai materi mengenai English for Business, English for Hospitality, dan English for General Communications. Lestari menyebutkan bahwa demonstrasi atau praktek berbahasa Inggris yang dicontohkan oleh Tim, memungkinkan para peserta untuk menggunakan Bahasa Iggris dengan benar ( Lestari \& Arfiandhani, 2021). Selain itu, Tim membekali Tiap peserta dengan modul panduan, sehingga memungkinkan mereka untuk belajar secara mandiri. Adapun untuk pendampingan berfokus pada aplikasi instrumen dalam kegiatan pembelajaran. Tahap evaluasi yaitu untuk mengetahui capaian peserta pelatihan dalam menguasai materi dan terampil dalam menerapkan instrumen penilaian menulis kreatif dengan pembelajaran daring

Pelatihan ini menggunakan model Group dimana peserta dikelompokkan kedalam kelompok kecil berisi sekitar 4 orang dengan 1 orang dari Tim yang mendampingi (Instruktur). Didalam Group itu sendiri instruktur menekankan keaktifan peserta untuk memahami materi sekaligus untuk diterapkan secara langsung. Dalam pelatihan bahasa Inggris ini metode yang diguanakan adalah metode dialog, diskusi kelompok dan demonstrasi. Adapun strategi pelaksanaan yang digunakan adalah 
strategi yang bersifat aksi-evaluasi-refleksi-revisi dengan menerapkan pembelajaran CTL (Contextual Teaching and Learning). Sasaran dari pengabdian pada masyarakat ini adalah 20 peserta yaitu Para Pekerja dari sektor Pariwisata terdampak Covid-19 yang berada di Desa Sesela, Kecamatan Gunungsari, Kabupaten Lombok Barat.

\section{Evaluating (Evaluasi)}

Tahap evaluasi yaitu untuk mengetahui capaian peserta pelatihan dalam menguasai materi dan terampil dalam menerapkan indikator yang menjadi acuan Tim PKM dalam pembelajaran (Rukayah, Jenny IS Poerwanti, Ahmad Syawaludin, 2021). Evaluasi ini juga bertujuan untuk mengetahui tingkat keberhasilan dari pelaksanaan kegiatan pelatihan yang dilakukan. (Permana et al, 2020; Rizka et al, 2018) Dalam hal ini disesuaikan dengan pembelajaran Speaking. Evaluasi dilakukan sejak dimulainya kegiatan sampai akhir kegiatan PKM dan menjadi pijakan pelaporan kegiatan. Adapun bahan evaluasi/ indikator keterlaksanaan program kerja PKM yaitu kesesuaian antara rencana program kerja dengan luaran yang dihasilkan dari kegiatan ini.

\section{Hasil dan Pembahasan}

Kegiatan PKM dengan judul "Pelatihan Upskilling Bagi Pekerja Sektor Pariwisata Terdampak Covid-19" telah selesai dilaksanakan. Berikut merupakan rincian kegiatan yang telah dilakukan:

Hasil pemantauan Tim PKM di salah satu pasar seni yang berada di Kabupaten Lombok Barat adalah kunjungan wisatawan mengalami penurunan yang drastis. Kunjungan wisatawan pada sektor penunjang pariwisata seperti Hotel, Rumah makan maupun usaha retail terpantau sepi. Pelaku usaha mengalami kerugian dan banyak yang terpaksa menutup tempat usahanya karena kendala operasional dan berkurangnya income. Sehingga para pelaku usaha bidang pariwisata banyak yang terdampak PHK atau dirumahkan. Para pengusaha akan membuka kembali usahanya dan memanggil kembali karyawan yang dirumahkan tersebut untuk bekerja apabila situasi sudah normal.

Pelatihan Upskilling bagi pekerja sektor pariwisata terdampak Covid-19 terlaksana dengan sangat baik. Kegiatan ini diawali dengan registrasi peserta. Selanjutnya, pada saat tim PKM memberikan paparan mengenai materi, terlihat para pekerja begitu antusias dan mereka juga menyampaikan keluh kesah mereka yang pada kondisi Covid 19 ini tidak bekerja dan membuat mereka sangat frustasi karena tidak dapat berkontribusi dengan maksimal untuk memberikan pemasukan atau income bagi keluarganya. Hal ini dapat di lihat pada Gambar 1 dimana para pekerja menyampaikan pendapat mereka. Mereka juga begitu antusias pada saat mengerjakan latihan soal dengan di damping oleh mahasiswa pendamping dan dosen.

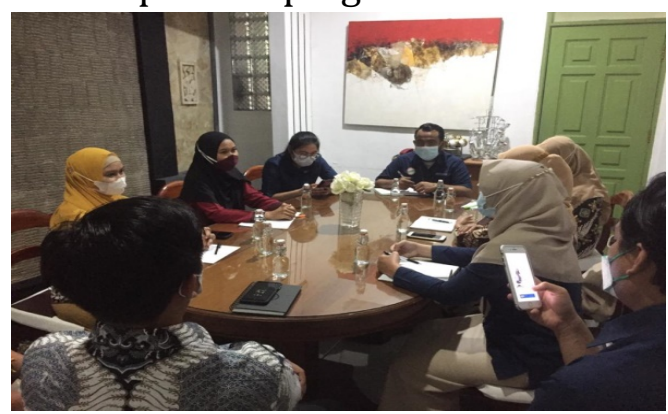

Gambar 1. Proses Diskusi Tim PkM dan Mitra 
Skill Para pekerja selama ini hanya mempunyai kemampuan berbahasa Inggris secara praktis dan kurang lancar. Mereka merasa tidak percayadiri untuk berkomunikasi dalam bahasa Inggris. Banyak juga yang mencampur bahasa inggris dengan bahasa Indonesia ketika mereka berkomunikasi dengan orang asing. Tentunya hal ini membuat komunikasi dua arah tidak efektif. Sehingga perlu adanya pelatihan untuk upskilling para pekerja khususnya dalam penggunaan bahasa Inggris Praktis.

Materi yang disampaikan oleh Tim PKM disampaikan dengan bahasa yang sederhana sehingga lebih mudah untuk di mengerti oleh para pekerja mengingat mereka tidak mempunyai latar belakang bahasa Inggris. Setelah Tim menyampaikan dan memaparkan materi, para pekerja diinstruksikan untuk mengerjakan soal latihan untuk mengetahui sejauh mana skill para pekerja dalam menggunakan bahasa Inggris praktis khususnya English for Business, English for Hospitality, dan English for General Communications. Hasil dari latihan soal menunjukkan bahwa terdapat peningkatan upskilling pekerja sektor pariwisata sejumlah $75 \%$ dalam menggunakan bahasa Inggris yang sesuai dengan kriteria of Speaking yang telah ditentukan.

Adapun respond Para Pekerja terdampak Covid-19 dalam Upskilling kompetensi bahasa Inggris mereka untuk dapat berkomunikasi dengan lebih optimal kepada para tamu mancanegara adalah sebagai berikut:

Berdasarkan angket kepuasan, pelatihan yang dilaksanakan ini dirasakan sangat bermanfaat bagi para pekerja dalam peningkatan kemampuan bahasa Inggris praktis mereka. Materi mengenai English for Business, English for Hospitality, dan English for General Communications sesuai dengan kebutuhan para pekerja dan penyampaiannya pun dilakukan dengan menarik dan mudah untuk dimengerti. Hasil pengamatan pada saat kegiatan PKM ini berlangsung dari tanggal 29 April 2021-17 Mei 2021 yaitu:

1. Para pekerja terlihat tertarik dan antusias mendengarkan paparan dari Tim PKM mengenai English for Business, English for Hospitality, dan English for General Communications.

2. Para pekerja begitu aktif berpartisipasi pada saat sesi tanya jawab.

3. Para pekerja secara keseluruhan memahami dan menguasai materi English for Business, English for Hospitality, dan English for General Communications. Hal ini ditunjukkan oleh hasil jawaban latihan soal yang sesuai dengan kriteria speaking.

Mengenai tingkat keberhasilan pelaksanaan kegiatan pelatihan, kemudian diukur dengan menggunakan angket kepuasan. Dimana pada angket ini terdapat 12 item pertanyaan yang terbagi dalam 3 kategori antara lain; manfaat kegiatan pelatihan ini bagi pekerja, cara penyajian materi oleh pembicara atau tutor. Skala yang digunakan dalam angket kepuasan yaitu empat antara lain: S untuk Setuju, SS untuk pilihan Sangat Setuju, TS untuk Tidak Setuju, serta STS untuk Sangat Tidak Setuju.

Angket diisi oleh seluruh pekerja dan hasil dari angket kepuasan secara umum menunjukkan bahwa kegiatan PkM yang telah dilaksanakan dirasakan bermanfaat bagi para pekerja. materi disampaikan dengan baik dan menarik. Pembicara yang dihadirkan juga dinilai baik. Rata-rata jawaban pada isian angket untuk seluruh item terlihat pada Gambar 2. Grafik yang ada pada Gambar 2 menunjukkan nilai rata rata terhadap pelatihan, dimana peserta mengisi sangat setuju dengan persentase sebesar $70 \%$ dan setuju sebesar 30\%. Hasil angket tidak menunjukkan isian tidak setuju dan juga sangat 
tidak setuju. Hasil tersebut menyatakan bahwa para peserta merasa sangat puas dengan pelatihan yang dilakukan.

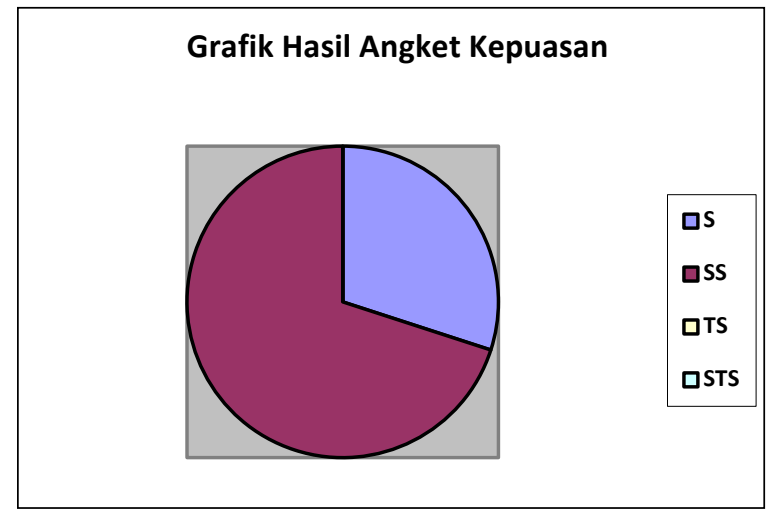

Gambar 2. Data Angket Kepuasan Peserta Pelatihan

Rata-rata nilai pada masing-masing kategori angket dapat dilihat di Tabel 1. Dimana hasil yang tertera pada Tabel 1 menunjukkan persentase rata-rata hasil angket pada kategori manfaat bagi peserta adalah 70\% menyatakan sangat setuju dan 30\% menyatakan setuju. Hal tersebut menunjukkan bahwa peserta merasa pelatihan yang diberikan bermanfaat. Persentase pada kategori penyajian materi menunjukkan ratarata nilai $67 \%$ menyatakan sangat setuju dan $33 \%$ menyatakan setuju. Hal ini menunjukkan bahwa para pekerja merasa bahwa penyajian materi yang diberikan sangat baik. Kategori pembicara menunjukkan persentase $74 \%$ yang menyatakan sangat setuju dan $26 \%$ menyatakan setuju. Sehingga dapat dikatakan bahwa pembicara yang dihadirkan dalam mengisi pelatihan sangat baik dan penyampaiannya mudah untuk diterima oleh para pekerja.

Tabel 1. Rata-rata Nilai Angket Per Katagori

\begin{tabular}{|c|c|c|c|c|}
\hline Katagori & $S$ & SS & TS & STS \\
\hline $\begin{array}{l}\text { Manfaat kegiatan ini bagi } \\
\text { peserta }\end{array}$ & $30 \%$ & $70 \%$ & $0 \%$ & $0 \%$ \\
\hline Penyajian Materi & $33 \%$ & $67 \%$ & $0 \%$ & $0 \%$ \\
\hline Pembicara & $26 \%$ & $74 \%$ & $0 \%$ & $0 \%$ \\
\hline
\end{tabular}

Adapun kendala yang dialami oleh Pekerja terdampak Covid-19 untuk Upskilling kompetensi bahasa Inggris mereka adalah keterbatasan waktu. Hal ini mengingat kegiatan dilaksanakan pada masa pandemic Covid-19 sehingga ada pembatasa waktu kegiatan. Para pekerja hanya mampu berkomunikasi dalam bahasa Inggris pada tingkat yang sederhana saja. Mengingat banyak diantara mereka yang Tamatan SD, SMP dan hanya beberapa saja yang menempuh Pendidikan hingga SMA. Sehingga upskilling difokuskan hanya pada English speaking skill saja. Mengenai materi yang disampaikan, para pekerja merasa perlu penjelasan lebih lanjut, maka tim PKM siap mendampingi secara virtual, dimana pekerja dapat menghubungi tim PKM baik itu melalui WhatsApp atau telpon apabila para pekerja memerlukan materi ataupun untuk berlatih. 


\section{Kesimpulan}

Kegiatan PKM ini dirasakan banyak manfaatnya bagi para Pekerja yang terdampak Covid-19. Mereka merasa banyak terbantu dengan kegiatan ini karena mereka dapat meningkatkan kemampuan (Upskilling skill) mereka dalam berkomunikasi dengan menggunakan bahasa Inggris dalam melayani costomer dari mancanegara, terutama materi English for Business, English for Hospitality, dan English for General Communications. Keberlanjutan kegiatan ini diharapkan untuk terus dilakukan paling tidak per semester, dan tetap diadakan pendampingan. Sehingga kemampuan para pakerja senantiasa terasah dan lebih maksimal dalam berkomunikasi dengan costumer mancanegara.

Rekomendasi Tim PKM eengingat sebagian besar dari para pekerja yang terdampak Covis-19 hanya lulus Sekolah Dasar, sehingga mereka akan lebih nyaman untuk menuliskan kosakata atau kalimat berbahasa Inggris dalam pelafalan masingmasing walaupun tidak sesuai dengan penulisannya. Karena kebutuhan mereka adalah mempraktekan speaking secara langsung, ringkas, singkat dan jelas. Selain itu, perlu dicipkatkan atmosfer pembelajaran yang menyenangkan dan tidak kaku serta disertai humor, sehingga membuat mereka semakin bersemangat dan percayadiri dalam mengikuti kegiatan ini.

\section{Ucapan Terimakasih}

Pelatihan ini terselenggara berkat dukungan dan kerjasama yang baik dari Para Pekerja terdampak Covid yang ada di Desa Sesela dengan Tim Pengabdian dari Prodi Bahasa Inggris FBMB. Terimaksih juga kepada LPPM UNDIKMA Mataram yang telah memberikan dukungan dana sehingga kegiatan ini terlaksana dengan hasil yang maksimal. Diharapkan, kegiatan ini dapat mencapai tujuannya untuk dapat mengoptimalkan Upskilling Pekerja yang terdampak Covid-19 pada sektor pariwisata. Sehingga mendukung daya saing dan dapat membangun kembali Industri Pariwisata domestik secara berkelanjutan.

\section{Referensi}

Cahyani D, R. (2020). Apindo: Industri Pariwisata Rugi Rp 21 Triliun Akibat Corona (Artikel Web). From https://bisnis.tempo.co/read/1335857/apindo-industripariwisata-rugi-rp-21-triliun-akibat-corona

Lystiana Nurhayat Hakim, Tri Agustini Solihati. (2021). Sosialisasi English for Young Learners (EYL) bagi Guru Sekolah. Aksiologiya: Jurnal Pengabdian Kepada Masyarakat, Vol. 5, No. 4,, $450-458$.

Salamah, I., Lindawat, Asriyadi, \& Kusumanto, R. (2021). Peningkatan Kemampuan Guru-Guru SD Negeri 130 Palembang Dalam Menyajikan Presentasi Atraktif Melalui Pelatihan Microsoft Power Point. Aksiologiya, Vol.4, No.1, (Februari 2020), 52-62.

Diyani, L. A., Kusumawati, R. D., \& Meita, I. (2021). Kemampuan Peningkatan Penyusunan Laporan Keuangan Sesuai SAK-EMKM. Aksiologiya: Jurnal Pengabdian Kepada Masyarakat, Vol.5 No.2, 222-232. 
Lestari, I. W., \& Arfiandhani, P. (2021). Peningkatan Kemampuan Bahasa Inggris Melalui Pelatihan Daring dengan Media Buku Anak Dwibahasa. Aksiologiya: Jurnal Pengabdian Kepada Masyarakat, Vol. 5, No. 4, 549 - 556.

Permana, D., Qomariyah, S., \& Rizka, M. (2020). Pelatihan Keterampilan Berkomunikasi Bahasa Inggris Bagi Pramusaji Kedai di Kawasan Wisata Aik Berik.Jurnal Pengabdian UNDIKMA: Jurnal Hasil Pengabdian dan Pemberdayaan Kepada Masyarakat, 1(1). doi:https://doi.org/10.33394/jpu.v1i1.2546

Rukayah, Jenny IS Poerwanti, Ahmad Syawaludin. (2021). PENDAMPINGAN PENYUSUNAN INSTRUMEN PENILAI-AN MENULIS KREATIF BAGI GURU-GURU SD DI KOTA SURAKARTA. Wikrama Parahita: Jurnal Pengabdian Masyarakat, Volume 5 Nomor 1, 33-37.

Ratna Dewi Kusumawati, Iren MeitaLucia Ari Diyani,. (2021). Peningkatan Kemampuan penyusunan Laporan Keuangan. Aksiologiya , 222-232.

Rizka, M. A., \& Tamba, W. (2019). Pelatihan Evaluasi Program Pendidikan Nonformal Bagi Pengelola Pusat Kegiatan Belajar Masyarakat (PKBM) di Kecamatan Gunungsari Kabupaten Lombok Barat. Paradharma (Jurnal Aplikasi IPTEK), 2(1).

Sujarwo, Y. (2020). Pelatihan Upskilling oleh Kemenparekraf bagi Pemandu Wisata di D.I Yogyakarta. (Artikel web). From http://www.dpchpi-kotajogja.org/artikelpelatihan-upskilling-oleh-kepemenparekraf-bagi-pemandu-wisata-di-diyogyakarta.

Esthi, R. B. (2020). Strategi Sumber Daya Manusia di Masa Pandemi dan New Normal Melalui Remote Working, Employee Productivity, Dan Upskilling For Digital. JPM: Jurnal Pengabdian Masyarakat, 1(1), 22-24.

Kusnedi, R. (2020). Pelatihan Bagi Guru Kewirausahaan Melalui Pembuatan Produk Kreatif Salah Satu Solusi Meningkatkan Kemampuan Guru Produktif Di SMK. Jurnal Pengabdian Masyarakat, 1(1), 45-52.

Jayantini, I. G. A. S. R., Sulatra, I. K., Candra, K. D. P., \& Ariyaningsih, N. N. D. (2020). Pendampingan Masyarakat Desa Adat Putung Menanggulangi Dampak Sosial Pandemi COVID-19. WIDYABHAKTI Jurnal Ilmiah Populer , 3(1), 92-98.

Sunandi, E., Agustina, D., \& Fransiska, H. (2021). Pendampingan Perangkat Desa untuk Pelatihan Pembuatan Infografis Data Kependudukan Desa. Aksiologiya: Jurnal Pengabdian Kepada Masyarakat, Vol.5, No.2, 248-254.

Imansyah, Nur. Jauhari Indah. (2020). PHRI: 3.310 karyawan hotel di NTB dirumahkan akibat dampak COVID-19. (Artikel web). From https://www.antaranews.com/berita/1422517/phri-3310-karyawan-hotel-dintb-dirumahkan-akibat-dampak-covid-19.

S, A. (2021). Sinergi DUDI dalam Merdeka Belajar Kampus Merdeka (MBKM). in Prosiding Seminar Nasional Fakultas Pertanian UNS, (Vol. 5, No. 1). Semarang. 